\title{
PENERAPAN TAX PLANNING TERHADAP PPh \\ SEBAGAI UPAYA EFISENSI PEMBAYARAN PAJAK \\ (Studi Kasus Pada Perusahaan Jasa Angkutan Di Malang)
}

\author{
Nanik Wahyuni \\ Fakultas Ekonomi Universitas Islam Negeri Maulana Malik Ibrahim Malang \\ J1. Gajayana No. 50, Telepon (0341) 558881, Fax. (0341) 558881, \\ E-mail: feuinmlg@yahoo.co.id
}

\begin{abstract}
To the effect of observational it is subject to be to insofar know which income tax planning effectiveness that can be done by firm and to reach efficiency in paying taxes charges that shall pay firm. Base observational result and taxation problem study in particular about tax planning on, therefore writer can glean from that firm has applied effective so corporate tax planning can't economize taxes charges payment it. To economize taxes, expedition company ought to applies tax planning, which is with shift cost that don't be admitted fiskus as accrued expenses fiskus as deducted as productions. In shifts cost, firm shall regard impact of that cost shift. Meanwhile to avoid of corporate maximum tax rate gets to broadcast production as production of some taxpayer, which is with make proprietary branch office as new firm that includes in group firm, then broadcasts proprietary production corporate to that new firm. With that implement, firm can economize taxes who shall be paid to state, and that thrift gets to be utilized to do marketing region extension and for things what do get to increase quality and firm amount.
\end{abstract}

Key words : tax, tax planing, expedition company

Direktorat Jendral Pajak memberi kepercayaan penuh terhadap wajib pajak untuk menghitung, membayar dan melaporkan sendiri seberapa besar jumlah pajak yang harus dibayar sesuai dengan peraturan perundang-undangan perpajakan yang berlaku, atau yang lebih dikenal dengan self assesment system. Untuk dapat menghitung jumlah pajak yang harus dibayar, wajib pajak harus terlebih dahulu mengetahui besarnya penghasilan kena pajak dari laporan keuangan yang telah disusun sesuai dengan standar akuntansi dan ketentuan perpajakan yang berlaku. Perusahaan biasanya membuat dua macam laporan keuangan, yakni laporan keuangan komersil yang ditujukan sebagai laporan 
untuk pihak intern perusahaan dan pihak ekstern perusahaan, dan laporan keuangan fiskal yang disusun dengan tujuan sebagai bahan untuk mengisi laporan kepada pihak fiskus atau Direktorat Jendral Pajak yaitu berupa surat pemberitahuan (SPT) yang digunakan untuk melaporkan perhitungan dan pembayaran pajak yang terutang menurut ketentuan peraturan perundangundangan yang berlaku.

Setelah wajib pajak menghitung, membayar dan melaporkan sendiri seberapa besar jumlah pajak yang harus dibayar, maka tiba giliran fiskus untuk memperhitungkan kebenaran perhitungan yang telah dilakukan oleh wajib pajak, a pakah benar-benar telah sesuai dengan undang-undang perpajakan yang berlaku. Dengan adanya perhitungan kembali yang dilakukan oleh fiskus, maka wajib pajak harus benar-benar jeli dalam melakukan perhitungan pajak yang harus dibayar. Semakin pentingnya pajak sebagai komponen untuk diperhitungkan, membuat banyak perusahaan berusaha untuk melakukan tax planning (perencanaan pajak).

Perencanaan pajak bagi suatu perusahaan dimaksudkan untuk mengefisiensikan beban pajak yang harus dibayar kepada pemerintah melalui penghindaran pajak dengan tidak melanggar undang-undang perpajakan ( $\operatorname{tax}$ avoidance) bukan penghindaran pajak yang melanggar undang-undang (tax evasion). Dengan melakukan tax planning (perencanaan pajak), perusahaan dapat memperoleh penghasilan yang lebih besar, karena beban pajak yang harus dibayarkan lebih kecil dari sebelum perusahaan melakukan tax planning.

Dari uraian di atas, tulisan ini betujuan untuk untuk mengetahui sejauh mana efektifitas perencanaan pajak penghasilan yang dapat dilakukan oleh perusahaandan untuk mencapai efisiensi dalam pembayaran beban pajak yang harus dibayar perusahaan.

\section{PAJAK}

\section{Pengertian}

Dalam Anggaran Penerimaan dan Belanja Negara (APBN), penerimaan negara terbesar bersumber dari penerimaan pajak. Penerimaan dari sektor pajak menempati persentase yang paling tinggi dibandingkan sumber penerimaan negara yang lain. Oleh karena itu, pajak mempunyai peranan yang penting 
dalam membiayai pengeluaran-pengeluaran rutin negara. Banyak para ahli yang mengemukakan pengertian pajak, diantaranya pengertian pajak yang dikemukakan oleh Mardiasmo (2002:1) yaitu

Pajak adalah iuran rakyat kepada kas negara berdasarkan Undangundang (yang dapat dipaksakan) dengan tiada mendapat jasa balik (kontra prestasi) yang langsung ditujukan dan digunakan untuk membayar pengeluaran umum. Sedangkan pengertian pajak menurut Abut (2005:1) yaitu Pajak adalah iuran kepada negara, yang dapat dipaksakan dan terhutang oleh yang wajib membayarnya menurut peraturan, dengan tidak mendapat prestasi kembali yang langsung dapat ditunjuk, dan yang gunanya adalah untuk membiayai pengeluaran umum berhubungan dengan tugas negara untuk menjalankan pemerintahan.

\section{Perencanaan Pajak (Tax Planning)}

Pengertian perencanaan pajak menurut Suandy (2006:7) yaitu : “Merupakan langkah awal dalam manajemen pajak, pada tahap ini dilakukan pengumpulan dan penelitian terhadap peraturan perpajakan agar dapat diseleksi jenis tindakan penghematan pajak yang akan dilakukan."

Sedangkan pengertian perencanaan pajak (Tax Planning) menurut Resmi (2003:212) dapat diartikan sebagai “Upaya yang dilakukan oleh wajib pajak untuk menghemat pajak dengan cara mengatur perhitungan penghasilan yang lebih kecil yang dimungkinkan oleh perundang-undangan perpajakan."

Menurut Tjahjono (2005:475) perencanaan pajak diartikan sebagai proses mengorganisasi usaha wajib pajak atau kelompok wajib pajak sedemikian rupa sehingga utang pajaknya baik pajak penghasilan maupun pajak-pajak lainnya, berada dalam posisi yang minimal, sepanjang hal ini dimungkinkan oleh ketentuan peraturan perundang-undangan yang berlaku.

Jadi, pada dasarnya perencanaan pajak adalah usaha wajib pajak untuk mencapai efisiensi pembayaran beban pajak dengan meminimalisasi pembayaran beban pajak dengan tidak melanggar ketentuan yang telah di tetapkan dalam peraturan perpajakan atau Undang-undang perpajakan. Untuk dapat melakukan perencanaan pajak, terlebih dahulu harus mengerti dan memahami perundang-undangan perpajakan yang ada. Setelah memahami dan 
mengerti baru akan mengetahui kelemahan Undang-undang yang ada. Dari kelemahan- kelemahan yang ada itulah dapat dimanfaatkan sebagai celah untuk melakukan perencanaan pajak.

\section{Manfaat Perencanaan Pajak (Tax Planning)}

Menurut Mardiasmo (2006:277) Perencanaan Pajak (Tax Planning) memiliki manfaat pertama penghematan kas keluar, perencanaan pajak dapat menghemat pajak yang merupakan biaya bagi perusahaan. Kedua, mengatur alian kas (cash flow), Perencanaan pajak dapat mengestimasi keutuhan kas untuk pajak dan menentukan saat pembayaran sehingga perusahaan dapat menyusun budget kas secara tepat dan akurat.

Asumsi pajak sebagai unsur pengurang penghasilan menjadi motivasi para wajib pajak untuk melakukan perencanan pajak. Oleh karena itu dengan meminimalkan beban pajak maka sejumlah uang yang tersedia untuk membayar pajak dapat dialokasikan untuk pos-pos lain dalam perusahaan, atau untuk memenuhi kebutuhan perusahaan yang lainnya. Jika perusahaan dapat memenuhi seluruh kewajiban perpajakannya, maka upaya untuk meminimalkan beban pajak yang dapat meminimalkan pembayaran atas sanksi-sanksi perpajakan yang berlaku, akan dapat menghemat kas keluar.

Perencanaan pajak yang cermat dapat ditentukan dengan langkah yang tepat dalam mengestimasi kebutuhan kas untuk pajak dan menentukan saat pembayaran sehingga perusahaan dapat menyusun anggaran kas lebih akurat.

Sedangkan manfaat dari perencanaan pajak (Tax Planning) dalam Zain (2007:42) adalah "Mengefisiensikan jumlah pajak yang akan ditransfer ke pemerintah, sehingga dapat menghemat sebagian kas yang seharusnya dibayar dan dapat digunakan untuk kepentingan yang lainnya."

Jadi, manfaat perencanaan pajak (Tax Planning) adalah untuk menghemat kas yang dimiliki perusahaan dengan mengefisiensikan jumlah pajak yang harus dibayar kepada pemerintah.

\section{Langkah-langkah Dalam Melakukan Perencanaan Pajak}

Langkah-langkah yang dapat dilakukan dalam perencanaan pajak menurut Markus (2004:351) adalah : 
1. Mengusahakan agar terdapat penghasilan yang stabil untuk menghindarkan pengenaan pajak dari kelas penghasilan yang tarifnya tinggi (top rate brackets)

2. Mempercepat atau menunda beberapa penghasilan dan biaya-biaya untuk memperoleh keuntungan dari kemungkinan perubahan tarif pajak yang tinggi atau rendah, seperti penangguhan pengenaan PPN, PPN yang ditanggung pemerintah dan seterusnya.

3. Menyebarkan penghasilan menjadi penghasilan dari beberapa wajib pajak, seperti pembentukan grup-grup perusahaan.

4. Menyebarkan penghasilan menjadi penghasilan beberapa tahun untuk mencegah penghasilan tersebut termasuk dalam kelas penghasilan yang kelasnya tinggi dan tunda pembayaran pajaknya, seperti penjualan cicilan kredit dan seterusnya.

5. Transformasikan penghasilan sebagai Capital Gain jangka panjang.

6. Mengambil keuntungan sebesar-besarnya dari ketentuan-ketentuan mengenai pengecualian dan potongan.

7. Menggunakan uang dari hasil pembebasan pengenaan pajak untuk keperluan perluasan perusahaan yang mendapat kemudahankemudahan.

8. Memilih bentuk usaha terbaik untuk operasional usaha.

9. Mendirikan bentuk usaha dalam satu jalur usaha sedemikian rupa sehingga dapat diatur secara keseluruhan penggunaan tarif pajak, potensi penghasilan, kerugian-kerugian dan aset yang dapat dihapus.

Jadi, dalam melakukan perencanaan pajak perusahaan dapat mengambil langkah-langkah yang sekiranya cocok dengan kondisi perusahaan serta memilih langkah mana yang dapat memberikan penghematan pajak yang besar bagi perusahaan.

Dalam melakukan perencanaan pajak harus memperhatikan biaya-biaya yang diperbolehkan fiskus sebagai pengurang penghasilan, karena ada biaya yang dapat diakui sebagai pengurang dan ada yang tidak diakui sebagai pengurang. Biaya yang dapat diakui sebagai pengurang penghasilan misalnya biaya pembelian bahan baku, biaya gaji, biaya penyusutan. Sedangkan biaya yang tidak diakui sebagai pengurang penghasilan contohnya adalah biaya yang dikeluarkan untuk kepentingan pribadi, natura atau kenikmatan.

\section{METODE}

Dalam penelitian ini mencakup bidang perpajakan khususnya tentang perencanaan pajak dalam upaya efisiensi pembayaran beban pajak. Sampel dalam penelitian ini adalah Perusahaan Jasa Angkutan di Malang. Analisis yang 
digunakan adalah analisis deskriptif yang menguaraikan perencanaan pajak, antara lain :

1. Menyusun Laporan laba rugi untuk periode yang berakhir pada 31 Desember 2007.

2. Melakukan evaluasi terhadap biaya-biaya yang terkena koreksi fiskal.

3. Melakukan rekonsiliasi laporan keuangan.

4. Melakukan tahap-tahap perencanaan pajak yaitu :

a. Mengalihkan biaya-biaya yang terkena koreksi fiskal (Perencanaan Pajak Tahap I).

b. Menyebarkan penghasilan menjadi penghasilan dari beberapa wajib pajak (Perencanaan Pajak Tahap II).

5. Menghitung besarnya pajak yang bisa dihemat.

\section{Informasi Akuntansi}

Penyajian informasi akuntansi ini dilakukan untuk memudahkan di dalam menganalisis, sehingga diharapkan dapat membantu memecahkan permasalahan yang ada di dalam perusahaan khususnya dalam hal keuangan. Adapun informasi yang digunakan berupa data laporan keuangan yang berupa laporan laba rugi.

\section{PEMBAHASAN}

Perencanaan pajak (tax planning) adalah usaha yang dilakukan wajib pajak untuk meminimalkan jumlah pajak yang harus di bayar dengan tidak melanggar ketentuan perundang-undangan perpajakan yang berlaku. Adapun langkah-langkah yang peneliti lakukan dalam menerapkan perencanaan pajak (Tax Planning) pada Perusahaan Jasa Angkutan adalah sebagai berikut :

1. Menyusun laporan laba rugi untuk periode yang berakhir pada 31 Desember 2007.

2. Melakukan evaluasi terhadap biaya-biaya yang terkena koreksi fiskal.

Biaya-biaya yang terkena koreksi fiskal antara lain:

1. Biaya Tamu dan Hiburan, Biaya tamu dan hiburan merupakan biaya yang dikeluarkan untuk menjamu tamu yang datang dari kantor cabang maupun dari perusahaan lain yang ada ikatan kerja dengan Perusahaan. 
Karena tidak adanya bukti pendukung yang berupa surat perintah perjalanan dinas dari perusahaan, maka dianggap sebagai biaya yang dibebankan atau dikeluarkan untuk kepentingan pribadi dan tidak boleh dikurangkan dari penghasilan perusahaan. Hal ini disesuaikan dengan Undang-undang Pajak Penghasilan Tahun 2000 pasal 9 ayat (1) huruf b, bahwa untuk menentukan besarnya Penghasilan Kena Pajak bagi wajib pajak dalam negeri dan bentuk usaha tetap tidak boleh dikurangkan biaya yang dibebankan atau dikeluarkan untuk kepentingan pribadi pemegang saham, sekutu, atau anggota.

b. Biaya Pengobatan, Biaya pengobatan tidak boleh dikurangkan dari penghasilan perusahaan. Hal ini disesuaikan dengan Undang-undang Pajak Penghasilan Tahun 2000 pasal 9 ayat (1) huruf e, bahwa untuk menentukan besarnya Penghasilan Kena Pajak bagi wajib pajak dalam negeri dan bentuk usaha tetap tidak boleh dikurangkan penggantian atau imbalan sehubungan dengan pekerjaan atau jasa yang diberikan dalam bentuk natura atau kenikmatan, kecuali penyediaan makanan dan minuman bagi seluruh pegawai serta penggantian atau imbalan dalam bentuk natura dan kenikmatan di daerah tertentu dan yang berkaitan dengan pelaksanaan pekerjaan yang ditetapkan dengan keputusan menteri keuangan.

c. Biaya Konsumsi, ini hanya diberikan kepada pimpinan, wakil pimpinan, kepala bagian pemasaran, kepala bagian keuangan dan kepala bagian operasional. Oleh karena itu biaya konsumsi tidak boleh dikurangkan dari penghasilan perusahaan. Hal ini disesuaikan dengan Undangundang Pajak Penghasilan Tahun 2000 pasal 9 ayat (1) huruf e, bahwa untuk menentukan besarnya Penghasilan Kena Pajak bagi wajib pajak dalam negeri dan bentuk usaha tetap tidak boleh dikurangkan penggantian atau imbalan sehubungan dengan pekerjaan atau jasa yang diberikan dalam bentuk natura atau kenikmatan, kecuali penyediaan makanan dan minuman bagi seluruh pegawai serta penggantian atau imbalan dalam bentuk natura dan kenikmatan di daerah tertentu dan yang berkaitan dengan pelaksanaan pekerjaan yang ditetapkan dengan keputusan menteri keuangan. 
3. Melakukan rekonsiliasi laporan keuangan.

Dalam laporan keuangan komersial dan laporan keuangan fiskal terdapat perbedaan. Hal ini disebabkan karena adanya perbedaan pengakuan penghasilan dan biaya. Agar tidak terjadi perbedaan pengakuan penghasilan dan biaya antara laporan keuangan komersial dan fiskal diperlukan rekonsiliasi laporan keuangan.

4. Melakukan tahap-tahap perencanaan pajak (Tax Planning).

a. Mengalihkan biaya-biaya yang terkena koreksi fiskal sesuai dengan Undang-undang Pajak Penghasilan Tahun 2000 (Perencanaan Pajak Tahap I) dan menyusun laporan laba rugi setelah perencanaan pajak tahap I.

1) Biaya Tamu dan Hiburan, merupakan biaya yang dikeluarkan untuk menjamu tamu yang datang dari kantor cabang maupun dari perusahaan lain yang ada ikatan kerja dengan Perusahaan. Karena tidak adanya bukti pendukung yang berupa surat perintah perjalanan dinas dari perusahaan, maka dianggap sebagai biaya yang dibebankan atau dikeluarkan untuk kepentingan pribadi dan tidak boleh dikurangkan dari penghasilan perusahaan. Dalam kaitannya dengan penerapan perencanaan pajak, agar diakui sebagai biaya oleh fiskus, maka setiap tamu yang datang wajib disertai dengan surat perintah perjalanan dinas (SPPD) dari perusahaan. Dengan adanya surat perintah perjalanan dinas, maka dapat diketahui bahwa kedatangan tamu tersebut bukan untuk kepentingan pribadi, tetapi untuk melaksanakan tugas dari perusahaan. Hal ini sesuai dengan Undang-undang Pajak Penghasilan Tahun 2000 Pasal 6 ayat (1) huruf a, bahwa untuk menentukan besarnya penghasilan kena pajak bagi wajib pajak dalam negeri dan bentuk usaha tetap, ditentukan berdasarkan penghasilan bruto dikurangi biaya untuk mendapatkan, menagih, dan memelihara penghasilan, termasuk biaya pembelian bahan, biaya berkenaan dengan pekerjaan atau jasa termasuk upah, gaji, honorarium, bonus, gratifikasi, dan tunjangan yang diberikan dalam bentuk uang, bunga, sewa, royalti, biaya perjalanan, biaya 
pengolahan limbah, premi asuransi, biaya administrasi, dan pajak kecuali pajak penghasilan.

2) Biaya Pengobatan, tidak dapat dikurangkan dari penghasilan bruto karena merupakan penggantian atau imbalan sehubungan dengan pekerjaan atau jasa yang diberikan dalam bentuk natura atau kenikmatan ( sesuai pasal 9 ayat (1) huruf e Undang-undang Pajak Penghasilan Tahun 2000). Untuk dapat dijadikan sebagai biaya yang dapat dikurangkan dari penghasilan bruto, maka perusahaan seharusnya dapat melakukan perencanaan pajak (Tax Planning) dengan mengalihkan biaya pengobatan menjadi premi asuransi kesehatan, dan premi tersebut dicatat dalam daftar gaji karyawan. Pasal 9 ayat (1) huruf d menyatakan bahwa untuk menentukan besarnya Penghasilan Kena Pajak bagi wajib pajak dalam negeri dan bentuk usaha tetap tidak boleh dikurangkan premi asuransi kesehatan, asuransi kecelakaan, asuransi jiwa, asuransi dwiguna dan asuransi beasiswa yang dibayar oleh wajib pajak orang pribadi, keculai jika dibayar oleh pemberi kerja dan premi tersebut dihitung sebagai penghasilan bagi wajib pajak yang bersangkutan.

3) Biaya Konsumsi, ini hanya diberikan kepada pimpinan, wakil pimpinan, kepala bagian pemasaran, kepala bagian keuangan dan kepala bagian operasional. Karena tidak diberikan kepada semua pegawai, maka biaya konsumsi ini tidak diakui oleh fiskus. Agar dapat diakui sebagai biaya oleh fiskus, maka sebaiknya biaya konsumsi ini dialihkan menjadi biaya konsumsi karyawan yang diwujudkan dengan penyediaan makanan dan minuman bagi seluruh pegawai. Hal ini sesuai dengan Undang-undang Pajak Penghasilan Tahun 2000 pasal 9 ayat (1) huruf e.

b. Menyebarkan Penghasilan Menjadi Penghasilan dari Beberapa Wajib Pajak (Perencanaan Pajak Tahap II). Salah satu langkah dalam melakukan perencanaan pajak adalah dengan menyebarkan penghasilan menjadi penghasilan dari beberapa wajib pajak. Langkah ini dapat ditempuh dengan menjadikan kantor-kantor cabang yang dimiliki Perusahaan menjadi perusahaan baru yang 
termasuk dalam kelompok (group) perusahaan, hal ini dapat dilihat pada Tabel 1 di bawah ini:

\section{Tabel 1}

Pembagian Kelompok (group) Perusahaan

\begin{tabular}{|l|l|}
\hline \multicolumn{1}{|c|}{ Kantor Cabang } & \multicolumn{1}{c|}{ Perusahaan Baru } \\
\hline Jakarta & PT. A \\
\hline Malang dan Surabaya & PT. B \\
\hline
\end{tabular}

Untuk mendirikan perusahaan baru, perusahaan harus mengeluarkan kas untuk biaya pendirian perusahaan. Menurut Andhyka Consulting yang beralamatkan di Gedung Pulomas Satu GD-V Lt. 3 No. 14 Jl. Jend. Achmad Yani No. 2 Jakarta 13210, biaya paket pendirian PT adalah :

- PT - Golongan Besar : : Rp. 12.750.000,-

- PT - Golongan Menengah : Rp. 10.750.000,-

- PT - Golongan Kecil : : Rp. 8.750.000,-

Jadi dapat diketahui biaya untuk mendirkan 2 (dua) perusahaan baru yakni kurang lebih Rp. 25.500.000,--

Pendirian perusahaan baru ini juga ditujukan untuk membagi daerah pemasaran. . Dengan adanya pembagian daerah pemasaran tersebut, maka daerah pemasaran perusahaan akan semakin luas dan bisa menjangkau semua kota yang ada di Pulau Jawa ini.

Perusahaan juga harus menyesuaikan membuat tarif yang digunakan untuk pengiriman barang antar kota yang satu dengan kota yang lainnya. Penentuan tarif dapat dihitung berdasarkan jauh dekatnya jarak yang harus di tempuh dalam pengiriman barang:

5. Menghitung Besarnya Pajak Yang Bisa Dihemat 
Terdapat perbedaan besarnya pajak penghasilan sebelum perencanaan pajak dan sesudah perencanaan pajak. Apabila tanpa perencanaan pajak, maka perusahaan akan mengeluarkan kas untuk membayar pajak lebih besar setiap tahunnya daripada setelah atau dengan melakukan perencanaan pajak tahap I dan tahap II. Jadi dalam hal ini perusahaan dapat menghemat kas. Selisih ini jelas menguntungkan bagi perusahaan yang berusaha untuk menghemat beban pajaknya.

Namun, untuk melakukan perencanaan pajak Tahap II ini, perusahaan harus mengeluarkan sejumlah kas untuk pembiayaan perijinan pendirian badan usaha (PT). Biaya yang dibutuhkan untuk pendirian 2 (dua) badan usaha PT. A dan PT. B kurang lebih Rp. 25.500.000,-. Sesuai dengan Standart Akuntansi yang berlaku menerangkan bahwa biaya pendirian tidak boleh dibebankan langsung pada tahun awal pendirian, tetapi harus di amortisasi selama lima tahun. Jadi, dengan melakukan perencanaan pajak tahap I dan tahap II, perusahaan akan mendapatkan keuntungan yang lebih besar dibandingkan dengan menyimpan uang yang digunakan untuk biaya pendirian perusahaan di bank.

\section{KESIMPULAN DAN SARAN}

\section{Kesimpulan}

1. Perusahaan jasa angkutan di Malang belum menerapkan perencanaan pajak yang efektif sehingga perusahaan tidak dapat menghemat pembayaran beban pajaknya. Hal ini terbukti dengan adanya biaya-biaya yang dianggap bukan sebagai biaya oleh fiskus. Biaya-biaya tersebut adalah Biaya Tamu dan Hiburan, Biaya Pengobatan, Biaya Konsumsi. Dengan tidak diakuinya biaya-biaya tersebut akan berpengaruh dalam menentukan besarnya penghasilan kena pajak yang menjadi dasar penentuan pajak yang harus dibayar, sehingga pajak yang harus dibayar menjadi lebih besar dari yang dilaporkan oleh perusahaan. 
2. Selain itu, Perusahaan seharusnya bisa lebih menghemat pajaknya, yaitu dengan menyebarkan penghasilan menjadi penghasilan dari beberapa wajib pajak. Langkah ini dapat ditempuh dengan menjadikan kantor-kantor cabang yang dimiliki menjadi perusahaan baru yang termasuk dalam kelompok (group) perusahaan. Dengan melakukan penyebaran penghasilan perusahaan akan terhindar dari tarif pajak maksimum.

\section{Saran}

1. Untuk menghemat pajak, perusahaan jasa angkutan hendaknya menerapkan perencanaan pajak (tax planning), yaitu dengan mengalihkan biaya-biaya yang tidak diakui fiskus menjadi biaya yang diakui fiskus sebagai pengurang penghasilan dan untuk menghindarkan dari tarif pajak maksimum perusahaan dapat menyebarkan penghasilan menjadi penghasilan dari beberapa wajib pajak.

2. Untuk mengalihkan biaya yang tidak diakui fiskus agar dapat diakui fiskus, perusahaan juga harus mempertimbangkan dampak dari pengalihan biaya tersebut. Misalnya biaya konsumsi yang dialihkan menjadi biaya konsumsi karyawan, semula biaya konsumsi hanya diperuntukan bagi beberapa orang, tetapi setelah dialihkan menjadi biaya konsumsi kantor maka pengeluaran untuk konsumsi akan bertambah, karena diperuntukkan bagi semua karyawan. Jadi perusahaan bisa menghemat pajak yang harus dibayar tetapi perusahaan juga harus mengeluarkan biaya yang lebih besar.

3. Perusahaan dapat menjadikan kantor-kantor cabang yang dimiliki menjadi perusahaan baru yang termasuk dalam kelompok (group) perusahaan, kemudian menyebarkan penghasilan yang dimiliki perusahaan ke perusahaan baru tersebut. Dengan penerapan tersebut, perusahaan dapat menghemat pajak yang harus dibayar kepada Negara.

4. Perusahaan juga harus mengikuti peraturan perpajakan yang berlaku, yang selalu berubah-ubah dan diperbaharui. Hal ini perlu diupayakan untuk menghindari terjadinya peristiwa yang oleh fiskus dapat dianggap sebagai tindakan yang dapat digolongkan dalam penggelapan pajak (tax evasion).

\section{DAFTAR PUSTAKA}


Mardiasmo. 2002. Perpajakan. Edisi Revisi. Yogyakarta: Andi Offset.

Supramono. 2005. Perpajakan Indonesia Mekanisme dan Perhitungan. Yogyakarta: Andi Offset.

Mardiasmo. 2006. Perpajakan. Edisi Revisi. Yogyakarta: Andi Offset.

Suandy, Early. 2006. Perencanaan Pajak. Edisi Ketiga. Jakarta: Salemba Empat.

Abut, Hilarius. 2005. Perpajakan. Jakarta: Diadit Media.

Suandy, Early. 2006. Perpajakan. Edisi Ketiga. Jakarta: Salemba Empat.

Waluyo, Ilyas, Wirawan, B. 2006. Perpajakan Indonesia: Penyesuaian dengan Ketentuan Peraturan Perundang-Undangan Perpajakan Terbaru Tahun 2001. Edisi Ketujuh. Jakarta: Salemba Empat.

Resmi, Siti. 2003. Perpajakan: Teori dan Kasus. Jakarta: Salemba Empat.

Zain, Mohammad. 2007. Manajemen Perpajakan. Jakarta: Salemba Empat.

Fitriandi, Primandita. 2007. Kompilasi Undang-undang Perpajakan Terlengkap. Jakarta: Salemba Empat.

Tjahjono, Achmad dan Husein, Fakri, Muhammad. 2005. Perpajakan. Edisi Ketiga. Yogyakarta: UUP AMP TKPN.

Markus, Muda dan Yujana, Hendry, Lalu. 2004. Pajak Penghasilan. Edisi Revisi. Jakarta: Gramedia Pustaka Utama.

Meliala, Tulis, S. 2007. Perpajakan dan Akuntansi Pajak. Edisi Keempat. Semesta Media. 